\title{
The Impact of Culture and Gender on Impoliteness Strategies in Jordanian and American TV Sitcoms
}

\author{
Bayan B. Rababa'h \\ University of Jordan, Amman, Jordan \\ Ghaleb Rabab'ah \\ University of Sharjah, UAE
}

\begin{abstract}
Several studies examined the effect of gender, culture and context on the use of impoliteness strategies. The present study examined the gender and cultural differences and similarities in the language used in Jordanian and American TV sitcoms. The researchers analysed 30 episodes from the Jordanian TV sitcom "dzalt'ah/جلطة/season 1" and 20 episodes from the American TV sitcom "The Big Bang Theory/season 12", which make a total of about $\mathbf{4 0 0}$ minutes from each sitcom. The findings of the study indicate that male characters employed impoliteness strategies more than female characters in both cultures. It was also found that Jordanian characters utilized more impoliteness strategies than the American characters. Jordanian males and females differed significantly in using impoliteness strategies; however, the differences between American males and females were not significant.
\end{abstract}

Index Terms - culture, gender, impoliteness, TV sitcoms, face threatening

\section{INTRODUCTION}

Impoliteness has been one of the most controversial issues in pragmatics research. As stated by Watts (2003, p. 9), "(im)politeness is a term that is struggled over at present, has been struggled over in the past and will, in all probability, continue to be struggled over in the future." This controversy has been noticed in the definition of the term 'impoliteness'. Brown and Levinson's (1987) politeness theory proposes that politeness is achieved by an attempt to protect the addressee's face, which is defined as "the public self-image that every member wants to claim for himself" (p. 61). Hence, acts that attack the addressee's face are considered impolite. According to Culpeper et al. (2003, p. 1546), impoliteness is described as encompassing "communicative strategies designed to attack face, and thereby cause social conflict and disharmony". In keeping with Brown and Levinson (1987), Mills (2005, p. 268) considers impoliteness as "any type of linguistic behaviour which is assessed as intending to threaten the hearer's face or social identity." Culpeper (2005) modified his definition to include intentionality, and argues that "Impoliteness comes about when: (1) the speaker communicates face-attack intentionally, or (2) the hearer perceives and/or constructs behaviour as intentionally face-attacking, or a combination of (1) and (2)" (p. 38). This view was also supported by Bousfield (2008) who adds that "impoliteness constitutes the communication of intentionally gratuitous and conflictive verbal facethreatening acts which are purposefully delivered" (p. 72). Another important dimension of impoliteness is the role of social norms. Holmes et al. (2008) suggest that "verbal impoliteness [is] linguistic behaviour assessed by the hearer as threatening her or his face or social identity, and infringing the norms of appropriate behaviour that prevail in particular context and among particular interlocutors, whether intentionally or not" (p. 196).

Previous research has shown that politeness and impoliteness are influenced by several fcharacters such as culture and gender. Mills and Kadar (2011, p. 21) argue that "cultures are not homogeneous and that within each culture there are different views on what constitutes polite and impolite behaviours." Lakoff (1973) also found that women are more polite than men, which she explains as a reflection of the powerlessness and the lower status of women compared to men in human communities. This study extends this line of inquiry by tapping the role of gender and culture in the use of impoliteness strategies by Jordanian and American characters in TV sitcoms.

Television has gained much importance as an entertainment source for families. One of the most preferred genres for entertainment is comedy, which is found in many TV shows or programs. Recently, TV sitcoms have become an essential depiction of comedy. Shows are acted in front of an audience who uses laughter, applauses, and so on, to show what is funny in the performance and what is not (Neale and Krutnik, 1990). Mills (2009) defines TV sitcoms as situational comedy. Series in which a fixed number of characters act in a domestic or professional setting. TV sitcoms have become successful not only because they are funny, but also because of "the eligibility of characters, setting, and the narrative" (Mills, 2009, p. 16). 
Impoliteness strategies are used in TV sitcoms in order to make the audience laugh. Previous studies concluded that comedy and humour are male-dominant genres in TV sitcoms (Mills, 2009). As mentioned in the previous section, most studies have concluded that females use impoliteness less than males. The present study aims to explore how male and female characters utilize impoliteness strategies in the Jordanian TV sitcom /dzalt $\mathrm{f} a h$ / 'جلطة' and the American TV sitcom 'The Big Bang Theory'. The study also aims to find any cultural similarities and differences in the use of impoliteness strategies in the two sitcoms. The chosen episodes from the two sitcoms were on-screen in 2018 which means that they are from the most recent sitcoms on TV.

\section{A. Impoliteness and Culture}

Culture is generally defined as attitudes, beliefs, and values of a community. Spencer-Oatey (2008) stated that "culture is a fuzzy set of attitudes, beliefs, behavioural conventions, and basic assumptions and values that are shared by a group of people, and that influence each member's behaviour and each member's interpretations of the 'meaning' of other people's behaviour" (p. 16). Since different cultures refer to different beliefs, it may be the case that impoliteness also differs from one culture to another. What is considered polite in one culture might be considered impolite in another and vice versa; thus, when examining impoliteness, cultural differences must be considered (Mills, 2009). Different forms of language are linked to different values and beliefs in different cultures, which sometimes causes pragmatic failure during communications. Therefore, it is difficult to propose universal rules for the use of impoliteness strategies across cultures since each language has its own culture-specific pragmatic fcharacters. As a concept, impoliteness is universal; however, the strategies used to employ impoliteness differ from one culture to another.

In this respect, Kádár and Mills (2011) argue that "cultural norms are mythical; the nation, whatever we take that to mean, cannot speak with one voice, according to one view of what is appropriate or inappropriate. At any one time, there will be a range of different norms or notions of appropriateness circulating within the Communities of Practice and within the culture as a whole" (p. 43). This indicates that different cultures lead to different interpretations of utterances. One example of different cultural interpretations might be impoliteness which differs in the strategies used by different cultures. This claim is supported by Sinkeviciute's (2017) and Kecskes' (2015) findings that cultural differences impact on impoliteness acts.

According to Kecskes (2015), impoliteness strategies used in intercultural communications are different from strategies used by interlocutors who belong to the same culture. He suggests that the interpretation of impoliteness strategies is not only affected by language but also by the context, the topic, and the interlocutors' background. Furthermore, the interpretation of politeness and impoliteness strategies is controlled by the semantic analysability of the utterance articulated by the interlocutors. Kecskes (2015) concludes that impoliteness may not be recognized by interlocutors from different cultures.

\section{B. Impoliteness and Gender}

Gender is also considered to be one of the most important social fcharacters that has an impact on the use of language in general and the use of impoliteness strategies in particular. According to Lakoff (1973), women were found to be more polite than men, which was attributed to the powerlessness and the lower status of women compared to men in human communities. Following Lakoff's (1973) conclusion, later studies on gender proved the marginal status of women and how it is reflected on their language use compared to men. Lakoff (1973) stated that "men and women speak differently; women tend to use hedges and tag questions more in their speech" (Lakoff, 1973, cited in Eckert and McConnell-Ginet, 2013, p. 38).

Tannen (1990) supported the difference between the two genders and clarified how men and women regard social interaction differently. According to Tannen (1990), men view the world as a "battlefield", and they consider conversations as "negotiations in which people try to achieve and maintain the upper hand" (p. 9). Nonetheless, women look at the world as if it is a "network of relationships" and they consider conversations as "negotiations for closeness in which people try to seek and give confirmation and support, and to reach consensus" (p. 9). Tannen's (1990) conclusion explains why women avoid the use of impolite utterances more often than men for the sake of maintaining closeness and creating a network of relationships.

This relationship between gender and impoliteness has been examined by many scholars in the fields of pragmatics and sociolinguistics (Mills, 2002; Bousfield, 2008; Mirhosseini et al., 2017; Abdul Ghani, 2018). The results of such studies revealed that males tend to use more impoliteness strategies than females, a finding that leads some societies to associate impoliteness with men rather than women.

\section{Theoretical Framework}

Several models of impoliteness have been proposed by researchers. For example, Culpeper (1996) defined impoliteness as encompassing communicative strategies designed to attack the face of the addressee. Another researcher is Bousfield (2008) who agreed with Culpeper's (1996) impoliteness definition but added the notion of intentionality. Both scholars stated that the main difference between politeness and impoliteness is whether the interlocutor's intention supports or attacks the addressee's face. Culpeper (1996) proposed his impoliteness framework based on Brown and Levinson's (1987) politeness framework. The present study will use Bousfield's (2008) framework of impoliteness to 
investigate and analyse the impoliteness strategies employed by the male and female characters of the American TV sitcom "The Big Bang Theory" and the Jordanian TV sitcom "Dzalt'ah/"

Bousfield (2008) investigated and elaborated the strategies suggested by Culpeper (1996) and added four more strategies which are:

1. Criticize - dispraise hearer, some action or inaction by hearer, or some entity in which hearer has invested face.

2. Hinder/block - physically (block passage), communicatively (deny turn, interrupt).

3. Enforce role shift-force hearer out of one social and/or discoursal role into another.

4. Challenges. - ask the hearer a challenging question, question the hearer's position, stance, beliefs, and so on.

(Bousfield, 2008, p. 125-134)

\section{Aims of the Study}

The present study aims to find gender- and culture-related differences in the use of impoliteness strategies in Jordanian and American TV sitcoms. There are four research questions that form the focus of the study:

1- What are the impoliteness strategies used by the characters in the Jordanian TV sitcom "dzalt`ah/جلطة "جa"?

2- What are the impoliteness strategies used by the characters in the American TV sitcom "The Big Bang Theory"?

3- What are the cultural differences and similarities between the impoliteness strategies used in the Jordanian and the American TV sitcoms?

4- What are the gender similarities and differences in the use of impoliteness strategies between Jordanian and American characters?

\section{E. Significance of the Study}

Impoliteness has attracted the attention of many scholars (Mills, 2002; Aydınoğlu, 2013, Culpeper, 2003, 2011). Despite the importance of culture in language use, previous studies did not compare the use of impoliteness strategies across cultures. This study is significant because it examines the impoliteness strategies used by males and females from two different cultures: Jordanian and American. It analyses two TV sitcoms from discourse and sociolinguistic perspectives. Since the present study will shed light on impoliteness, culture, and gender, it is hoped that it will contribute to previous linguistic studies on impoliteness. The present study may be beneficial for TV sitcoms, translators, and writers whose work is aimed at people from different cultures. Moreover, it may help educators in teaching cultural differences in language classrooms.

\section{REVIEW OF LITERATURE}

Examining impoliteness strategies as used by male and female participants has attracted the attention of many researchers who found that males use impoliteness strategies more frequently than females. Mills (2002), for example, assumed that there is a relationship between gender and politeness/impoliteness, so she investigated interactions between male and female university students in a departmental party. She concluded that although there are linguistic differences between the two genders, there is a prevalent stereotypical convention regarding the existence of impoliteness in both gender's discourse. Further studies examined gender differences in impoliteness use. One of these is Aydınoğlu (2013) who analysed impoliteness among male and female fictional actors in Geralyn Horton's plays. The researcher adopted both Culpeper's (1996) and Bousfield's (2008) models of impoliteness strategies and concluded that women avoid being impolite when speaking more than men. Similar to Aydınoğlu (2013), Yating (2014) explored the TV sitcom 'Friends' and studied gender differences in politeness and impoliteness strategies. Yating's (2014) findings corresponded with Aydınoğlu's (2013) findings in that women tend to use more polite strategies and expressions than men.

Another study on impoliteness and gender was conducted by Al-Shlool (2016) who investigated how Arab men and women differ in using impoliteness and politeness strategies in social media websites. The data were collected from the social media website, Facebook. The main focus of Al-Shlool's (2016) study is to examine the cross-gender differences and similarities in the use of politeness and impoliteness strategies in Arabic discourse on Facebook. The findings of the study revealed that politeness strategies are used more than impoliteness strategies by both genders even though the setting is informal, which is Facebook. The findings also show that males use more impoliteness strategies when the topic is related to politics; however, females use more politeness strategies when the topic is related to religion. AlShlool (2016) concludes that both gender and topic affect the use of politeness and impoliteness strategies. Moreover, Al-Yasin and Rabab'ah (2018) investigated the use of impoliteness strategies by African American characters in TV series. They have also examined the difference between African American males and females in the use of impoliteness strategies in TV series. Their findings support the previous research that males employ more impoliteness strategies than females do.

Mirhosseini et al. (2017) used Culpeper's (1996) impoliteness model to analyse the discourse of two actors, a male and a female, in an Iranian movie. The outcomes suggest that the male actor used more impoliteness strategies than the female actor which is in line with Abdul Ghani (2018) and Al-Shlool (2016). Mirhosseini et al. (2017) revealed that there is no clear-cut boundary between impoliteness strategies since more than one strategy can be used in one utterance. The results showed that the difference in the use of impoliteness strategies between males and females is because of the 
difference in power between the two genders; the Iranian community considers males higher in status than females, and this is reflected in the selected movie. This study supports the importance of culture and power in the use of impoliteness strategies as suggested by previous scholars. One more study on impoliteness and gender was conducted by Abdul Ghani (2018) to examine impoliteness strategies in customers' comments which express their dissatisfaction. In her study, Abdul Ghani (2018) used the impoliteness framework developed by Culpeper $(1996,2011)$ to analyse the collected data from the Facebook comments on the company's page. The findings of the study showed that male customers tend to use more impoliteness strategies than females in order to express hostility.

Cultural differences and impoliteness have been investigated by a number of scholars such as Kecskes (2015). He analysed impoliteness use in intercultural and intracultural interactions. The findings of the study revealed that impoliteness differs between cultures, and it might be evaluated differently between interlocutors who belong to different cultures. Sinkeviciute (2017) studied how culture affects the interpretation of some impoliteness uses. She observed how impoliteness in general and teasing in particular function in humorous interactions in two cultural contexts. The researcher compared the interpretation of impoliteness in two TV shows from different cultures, viz. Australian and British. The study concludes that impoliteness is not appreciated in the British culture; however, it is considered appropriate in some contexts among the Australians.

Moreover, social media platforms have attracted many scholars to elicit data for their studies. Similar to Abdul Ghani's (2018) methodology, Hammod and Abdul-Rassul (2017) used Facebook comments to investigate the impoliteness strategies used in English and Arabic Facebook comments taken from six different Facebook pages. The study aimed at investigating the impoliteness strategies used by the commenters as well as the factors that affect the use of these strategies. One important result was that the strategy withdraw politeness is not frequently found in online comments; moreover, no significant difference was found between the impoliteness strategies used in the English comments and the strategies used in the Arabic ones although different topics were discussed. Moreover, Rabab'ah and Alali (2019) investigated impoliteness in the readers' comments in Al-Jazeera channel news website, as well as exploring the impact of computer-mediated contextual factors on the use of impoliteness. Findings of the study revealed that there are distinctive features of Arabic impoliteness discourse on social media. Furthermore, the results of the study indicate that Arabic impoliteness is similar to English impoliteness in using curses to attack writers on social media.

The literature review has revealed that the use of impoliteness strategies has not been examined among different cultures. It is thus the aim of the present study to investigate the impoliteness strategies used by males and females in two different cultures, namely, the Jordanian and American cultures in two TV sitcoms.

\section{METhodology}

\section{A. Sample and Data Collection}

The sample of this paper includes 30 episodes from the Jordanian TV sitcom "dzalt解/season 1" and 20 episodes from the American TV sitcom "The Big Bang Theory/season 12". The two sitcoms represent two different cultures (American and Jordanian), which were both on-screen in 2018. It is worth noting that the duration rather than the number of episodes was the main concern of the sample selection; therefore, the episodes from both sitcoms make a total of about 400 minutes of duration from each sitcom. The episodes are watched and transcribed to find out the impoliteness strategies used by male and female characters in each sitcom. After that the researcher wrote all the impolite utterances and classified them according to the impoliteness frameworks used in the current study.

\section{B. Data Analysis}

The present study adopts a mixed-method approach. Thus, the data were analysed both quantitatively and qualitatively. The researcher examined the data to find cultural differences in using impoliteness strategies by the Jordanian and American actors. As for the quantitative analysis, the frequencies were calculated and presented using the statistical tests t-test and one-way ANOVA to find any statistically significant differences in the use of impoliteness strategies because of gender and culture. The impoliteness instances, which were made by the Jordanian and American actors, were classified according to Bousfield's (2008) impoliteness taxonomy, and they were tabulated for comparison. On the other hand, the qualitative analysis includes instances of impoliteness utterances which are presented with an explanation of how and why the impoliteness strategies were used in the TV sitcoms.

\section{RESULTS AND DISCUSSION}

This section presents the results of the study and discusses them in relation to previous literature. It consists of two main sections. The first provides a quantitative analysis of the use of impoliteness strategies by the Jordanian actors in /dzalt'ah/ جلطة' as well as the use of impoliteness strategies by the American actors in 'The Big Bang Theory'. Moreover, cultural and gender-related differences in the use of impoliteness strategies are shown by providing frequencies and percentages. The second section presents the qualitative analysis in which several excerpts within the context of the Jordanian and American TV sitcoms are given and explained in order to illustrate how the actors from different cultures and genders employ various types of impoliteness strategies.

\section{A. Quantitative Analysis}


Impoliteness strategies in the Jordanian TV sitcom 'dzalt'ah جلطة'

The analysis of /dzalt'ah/ جلطة' TV sitcom has shown that the Jordanian comedians use various types of impoliteness strategies. Table 1 below shows frequencies and percentages of the use of impoliteness strategies in the Jordanian TV sitcom /dzalt'ah/ 'جلطة'.

TABLE 1

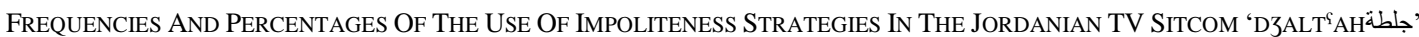

\begin{tabular}{|c|c|c|}
\hline Impoliteness strategies & Freq & $\%$ \\
\hline Criticize & 59 & 13.0 \\
\hline Hinder/block & 33 & 7.3 \\
\hline Enforce role shift & 2 & 0.4 \\
\hline Challenges & 16 & 3.5 \\
\hline Total & 110 & $100 \%$ \\
\hline
\end{tabular}

Table 1 indicates that the total number of impoliteness strategies used by Jordanian characters in Season 1 of 'dzalt'ahab is 110. The frequencies demonstrate that criticize is the most frequently used strategy, followed by Hinder/block and challenges, which registered 33 and 16, respectively. The table also shows that the least frequently used impoliteness strategy in 'dzalt 1 ahab is enforce role shift, which implies that the Jordanian characters prefer to attack the hearer's face by criticizing them or their actions in comedy TV sitcoms.

Gender differences in the Jordanian TV sitcom 'dzalt'ah جلطة'

The analysis of the Jordanian TV sitcom 'dzalt جلطة' has demonstrated that all Jordanian comedians use various types of impoliteness strategies. Table 2 and Table 3 present the frequencies, percentages and the T-test results related to the use of impoliteness strategies by the Jordanian male and female characters in the TV sitcom 'dzalt'ah'

TABLE 2

Frequencies AND PERCENTAges OF IMPOLITENESS STRATEGIES USED By JORDANIAN MALE AND FEMALE CHARACTERS

\begin{tabular}{|c|c|c|c|c|c|}
\hline \multirow[b]{2}{*}{ Impoliteness strategies } & \multicolumn{2}{|c|}{ Male } & \multicolumn{2}{|c|}{ Female } & \multirow[b]{2}{*}{ Total } \\
\hline & Freq & $\%$ & Freq & $\%$ & \\
\hline Criticize & 28 & 12.9 & 31 & 13.1 & 59 \\
\hline Hinder/block & 24 & 11.1 & 9 & 4.0 & 33 \\
\hline Enforce role shift & 2 & 0.9 & 0 & 0.0 & 2 \\
\hline Challenges & 15 & 6.9 & 1 & 0.4 & 16 \\
\hline Total & 69 & $100 \%$ & 41 & $100 \%$ & 110 \\
\hline
\end{tabular}

TABLE 3

T-TEST RESUlts For GENDER DifFERENCES In THE JORDANIAN TV SitCOM "IMPOLITENESS STRATEGIES"

\begin{tabular}{|c|c|c|c|c|c|}
\hline Impoliteness strategy & Gender & Mean & St. deviation & T-value & Sig. \\
\hline Criticize & Female & 1.0333 & 1.24522 & -.391 & .697 \\
\hline Hinder/block & Female & .3000 & .65126 & 2.063 & $.044 *$ \\
\hline \multirow[t]{2}{*}{ Enforce role shift } & Male & .0667 & .25371 & \multirow[t]{2}{*}{1.439} & \multirow[t]{2}{*}{.155} \\
\hline & Female & .0000 & .00000 & & \\
\hline
\end{tabular}

Table 4.2 shows that the most frequently used strategy by both Jordanian males and females is criticize (59 instances), followed by Hinder/block (33 instances) and challenges (16 instances). The least frequently used impoliteness strategy in 'dzalt'ah'جلطة' is enforce role shift by both males and females, which might suggest that both males and females employ impoliteness strategies in their utterances to make the audience laugh. The data also demonstrates that Jordanian male characters used the strategies hinder/block, challenges, and enforce role shift more than the female characters did; however, female characters employed the strategy criticize more than the male characters did. Another significant finding is that the Jordanian female characters did not use the strategy enforce role shift at all.

In order to determine if there are statistically significant differences between Jordanian male and female characters, $t$ test was used. Table 4.3 presents the T-test results of the of impoliteness strategies employed by male and female characters. The data analysis indicates that there are statistically significant differences $(\alpha .05)$ between the Jordanian male and female characters in the strategies hinder/block and challenges in favour of the male characters, implying that males used these strategies more. This could be due to the males' dominant role in the Jordanian culture since the use of these two strategies requires interruption and asking a challenging question. Furthermore, the data analysis reveals that there are no statistically significant differences between the Jordanian male and female characters in the use of the other strategies.

Impoliteness strategies in the American TV sitcom 'The Big Bang Theory'

The analysis of the American TV sitcom 'The Big Bang Theory' has revealed that the American comedians employ different impoliteness strategies to make their audience laugh. Table 4.4 below illustrates the frequencies and percentages of the use of impoliteness strategies in the American TV sitcom 'The Big Bang Theory'. 
TABLE 4

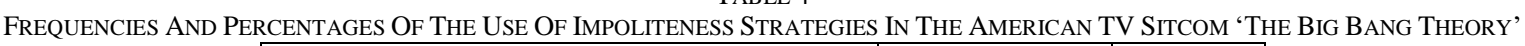

\begin{tabular}{|c|c|c|}
\hline Impoliteness strategies & Freq & $\%$ \\
\hline Criticize & 42 & 7.9 \\
\hline Hinder/block & 32 & 6.0 \\
\hline Enforce role shift & 1 & 0.2 \\
\hline Challenges & 24 & 4.5 \\
\hline Total & 99 & $100 \%$ \\
\hline
\end{tabular}

Table 4 reveals that the total number of impoliteness strategies used by the American characters in the TV sitcom 'The Big Bang Theory' is 99. The table also demonstrate that criticize is the most frequently used strategy by American characters (42), followed by Hinder/block (32.) and challenges (24). The data also shows that the least frequently used impoliteness strategy by the American characters is enforce role shift, which recorded only one instance, implying that the interlocutors do not prefer imposing the addressee to take turn in the conversation.

Gender differences in the American TV sitcom 'The Big Bang Theory'

The analysis of the American TV sitcom 'The Big Bang Theory' showed that the American comedians use different forms of impoliteness strategies to enact humour and make the audience laugh. Table 5 presents the frequencies and percentages of the impoliteness strategies used by the American male and female characters in the TV sitcom 'The Big Bang Theory'.

TABLE 5

FREQUENCIES AND PERCENTAGES OF IMPOLITENESS STRATEGIES USED BY AMERICAN MALE AND FEMALE CHARACTERS IN 'THE BIG BANG THEORY'

\begin{tabular}{|l|c|c|c|c|c|}
\hline & \multicolumn{2}{|c|}{ Male } & \multicolumn{2}{c|}{ Female } & Total \\
\hline Impoliteness strategies & Freq & $\%$ & Freq & $\%$ & 42 \\
\hline Criticize & 21 & 7.3 & 21 & 8.6 & 32 \\
\hline Hinder/block & 22 & 7.7 & 10 & 4.1 & 1 \\
\hline Enforce role shift & 0 & 0.0 & 1 & 0.4 & 24 \\
\hline Challenges & 12 & 4.2 & 12 & 4.9 & 99 \\
\hline \multicolumn{1}{|c|}{ Total } & 55 & $100 \%$ & 44 & $100 \%$ & 99 \\
\hline
\end{tabular}

Table 5 demonstrates that the total number of impoliteness strategies used by the American male and female characters in Season 12 of 'The Big Bang Theory' is 99; Males recorded 55 while females recorded 44. It is obvious that males registered more strategies than females did. As can be seen, the male characters used the strategy hinder/block more than the female characters did. It is also noticed that both male and female characters recorded the same number of strategies in criticize and challenges (21 and 12 each, respectively). The least frequently used impoliteness strategy in 'The Big Bang Theory' is enforce role shift, which was used only once by females.

Although the results of the table above indicate that the American male characters sometimes employed more impoliteness strategies than the female characters, the results of the T-test revealed that there are no statistically significant differences between the two groups in the use of impoliteness strategies. Such results differ from the results of the Jordanian characters, which indicated that there are significant differences between the two genders in the use of some impoliteness strategies.

T-test was conducted; its results demonstrated that gender differences in the use of impoliteness strategies were not statistically significant. This indicates that the American male and female characters employed impoliteness strategies similarly in context.

Cultural and gender differences in using impoliteness strategies

The data analysis revealed that there are cultural and gender differences in the use of impoliteness strategies in Arabic and English by Jordanian and American characters.

Cultural differences in using impoliteness strategies

The third research question of the present study deals with the similarities and differences in the use of impoliteness strategies between the Jordanian characters in the TV sitcom 'dzaltah'جلطة' and the American characters in the TV sitcom 'The Big Bang Theory'. Table 6 below presents the frequencies and percentages of impoliteness strategies used by Jordanian and American characters.

TABLE 6

FREQUENCIES AND PERCENTAGES OF IMPOLITENESS STRATEGIES USED BY JORDANIAN AND AMERICAN CHARACTERS

\begin{tabular}{|c|c|c|c|c|c|}
\hline & \multicolumn{2}{|c|}{ Jordanians } & \multicolumn{2}{|c|}{ Americans } & \\
\hline Impoliteness strategies & Freq & $\%$ & Freq & $\%$ & Total \\
\hline Criticize & 59 & 13.0 & 42 & 8.0 & 101 \\
\hline Hinder/block & 33 & 7.3 & 32 & 6.0 & 65 \\
\hline Enforce role shift & 2 & 0.4 & 1 & 0.2 & 3 \\
\hline Challenges & 16 & 3.5 & 24 & 4.5 & 40 \\
\hline Total & 110 & $100 \%$ & 99 & $100 \%$ & 209 \\
\hline
\end{tabular}

Table 6 reveals that the Jordanian characters in the TV sitcom 'dzalt'ah' recorded more impoliteness strategies than the American characters in the TV sitcom 'The Big Bang Theory'. Another significant finding is that the Americans recorded more challenges as impoliteness strategies than the Jordanians did. The least used strategy was 
enforce role shift by both groups; i.e., Jordanians and Americans. T-test was administered to show if there are significant differences in using impoliteness strategies between the Jordanians and the Americans in TV sitcoms; the results are presented in Table 7.

TABLE 7

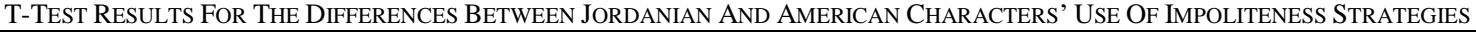

\begin{tabular}{|c|c|c|c|c|c|c|}
\hline Strategy & Nationality & Freq & Mean & $\begin{array}{c}\text { St. } \\
\text { deviation }\end{array}$ & T-value & Sig. \\
\hline \multirow[t]{2}{*}{ Criticize } & Jordanian & 59 & .9633 & .98276 & \multirow[t]{2}{*}{-.343} & \multirow[t]{2}{*}{.732} \\
\hline & American & 42 & 1.0500 & .90441 & & \\
\hline \multirow[t]{2}{*}{ Hinder/block } & Jordanian & 33 & .5500 & .96419 & \multirow[t]{2}{*}{-1.205} & \multirow[t]{2}{*}{.231} \\
\hline & American & 32 & .8000 & 1.09075 & & \\
\hline \multirow[t]{2}{*}{ Enforce role shift } & Jordanian & 2 & .0333 & .18102 & \multirow[t]{2}{*}{.237} & \multirow[t]{2}{*}{.813} \\
\hline & American & 1 & .0250 & .15811 & & \\
\hline \multirow[t]{2}{*}{ Challenges } & Jordanian & 16 & .2667 & .57833 & \multirow[t]{2}{*}{-2.173} & \multirow[t]{2}{*}{$.032 *$} \\
\hline & American & 24 & .6000 & .95542 & & \\
\hline
\end{tabular}

The T-test results revealed that there is a statistically significant difference in the use of impoliteness strategies between the Jordanian and American characters, which could be attributed to culture. The results indicate that there are statistically significant differences in the mean scores of the Jordanian and American characters' use of the strategy challenges in favor of the American characters. However, the results show that, although there are differences in the frequencies of use, there are no significant differences between Jordanian and American characters' use of the other impoliteness strategies, viz., criticize, hinder/block, and enforce role shift as shown in the mean scores in the Table 7. Table 4.8 presents the T-test results of the Jordanian and American male characters' use of impoliteness strategies.

TABLE 8

T-TEST RESUlts For THE DiFFERENCES BETwEEN JORDANIAN AND AMERICAN MALE CHARACTERS' IN ALL IMPOLITENESS STRATEGIES

\begin{tabular}{|c|c|c|c|c|c|c|}
\hline Impoliteness strategy & Nationality & Freq & Mean & St. deviation & T-value & Sig. \\
\hline \multirow[t]{2}{*}{ Criticize } & Jordanian & 28 & .9333 & .63968 & \multirow[t]{2}{*}{-.614} & \multirow[t]{2}{*}{.542} \\
\hline & American & 21 & 1.0500 & .68633 & & \\
\hline \multirow[t]{2}{*}{ Hinder/block } & Jordanian & 24 & .8000 & 1.15669 & \multirow[t]{2}{*}{-869} & \multirow[t]{2}{*}{.389} \\
\hline & American & 22 & 1.1000 & 1.25237 & & \\
\hline \multirow[t]{2}{*}{ Enforce role shift } & Jordanian & 2 & .0667 & .25371 & \multirow[t]{2}{*}{1.171} & \multirow[t]{2}{*}{.247} \\
\hline & American & 0 & .0000 & .00000 & & \\
\hline \multirow[t]{2}{*}{ Challenges } & Jordanian & 15 & .5000 & .73108 & \multirow[t]{2}{*}{-.451} & \multirow[t]{2}{*}{.654} \\
\hline & American & 12 & .6000 & .82078 & & \\
\hline
\end{tabular}

The t-test results displayed in Table 8 imply that there are no statistically significant differences between the Jordanian and American male characters in the total use of the four impoliteness strategies nor in the use of each of the strategies. The results imply that the Jordanian and American male characters employ the impoliteness strategies in the same manner in context.

The following tables present the results of the statistical analysis of the impoliteness strategies employed by the Jordanian and American female characters. T-test results concerning the Jordanian and American female characters' use of impoliteness major strategies in TV sitcoms are presented in Table 9.

TABLE 9

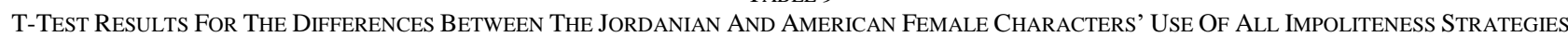

\begin{tabular}{|c|c|c|c|c|c|c|}
\hline Strategy & Nationality & Freq & Mean & St. deviation & T-value & Sig. \\
\hline \multirow[t]{2}{*}{ Criticize } & Jordanian & 31 & 1.0333 & 1.24522 & \multirow[t]{2}{*}{-.049} & \multirow[t]{2}{*}{.961} \\
\hline & American & 21 & 1.0500 & 1.09904 & & \\
\hline \multirow[t]{2}{*}{ Hinder/block } & Jordanian & 9 & .3000 & .65126 & \multirow[t]{2}{*}{-.954} & \multirow[t]{2}{*}{.345} \\
\hline & American & 10 & .5000 & .82717 & & \\
\hline \multirow[t]{2}{*}{ Enforce role shift } & Jordanian & 0 & .0000 & .00000 & \multirow[t]{2}{*}{-1.231} & \multirow[t]{2}{*}{.224} \\
\hline & American & 1 & .0500 & .22361 & & \\
\hline \multirow[t]{2}{*}{ Challenges } & Jordanian & 1 & .0333 & .18257 & \multirow[t]{2}{*}{-2.790} & \multirow[t]{2}{*}{$.008^{\prime}$} \\
\hline & American & 12 & .6000 & 1.09545 & & \\
\hline
\end{tabular}

Table 9 implies that there are statistically significant differences between the Jordanian and American female characters in the use of impoliteness strategies. More specifically, the differences are significant in the use of the strategy challenges in favour of the American female characters. The mean scores of the American characters' use of impoliteness strategies is higher than the Jordanian female characters, implying that the American female characters used more impoliteness strategies than the Jordanian female characters. Yet, the differences in the use of the other impoliteness strategies are not statistically significant.

Gender differences in using impoliteness strategies

The fourth research question of the present study deals with the gender similarities and differences in the use of impoliteness strategies between male and female characters in the Jordanian and American TV sitcoms. The one-way 
ANOVA analysis was used to find out if there are significant differences in the use of impoliteness strategies due to gender and language. Table 10 below presents the results of the One-way ANOVA analysis of both genders' use of impoliteness strategies.

TABLE 10

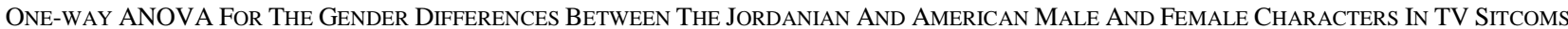

\begin{tabular}{|c|c|c|c|c|c|c|c|c|}
\hline . & & & Mean & $\begin{array}{c}\text { Sum of } \\
\text { squares }\end{array}$ & df & Mean square & $\mathbf{F}$ & Sig. \\
\hline \multirow[t]{5}{*}{ Criticize } & $\begin{array}{c}\text { Between } \\
\text { groups }\end{array}$ & Jordanian male & .9333 & .257 & 3 & .086 & .093 & .964 \\
\hline & \multirow[t]{3}{*}{ Within groups } & Jordanian female & 1.0333 & \multirow[t]{3}{*}{88.733} & \multirow[t]{3}{*}{96} & \multirow[t]{3}{*}{.924} & & \\
\hline & & American male & 1.0500 & & & & & \\
\hline & & American female & 1.0500 & & & & & \\
\hline & \multicolumn{2}{|c|}{ Total } & \multicolumn{2}{|c|}{88.990} & & & & \\
\hline \multirow[t]{5}{*}{ Hinder/block } & $\begin{array}{c}\text { Between } \\
\text { groups }\end{array}$ & Jordanian male & .8000 & 8.850 & 3 & 2.950 & 3.016 & $.034 *$ \\
\hline & \multirow[t]{3}{*}{ Within groups } & Jordanian female & .3000 & \multirow[t]{3}{*}{93.900} & \multirow[t]{3}{*}{96} & \multirow[t]{3}{*}{.978} & & \\
\hline & & American male & 1.1000 & & & & & \\
\hline & & American female & .5000 & & & & & \\
\hline & \multicolumn{3}{|c|}{ Total } & 102.750 & 99 & & & \\
\hline \multirow[t]{5}{*}{ Enforce role shift } & $\begin{array}{l}\text { Between } \\
\text { groups }\end{array}$ & Jordanian male & .0677 & .093 & 3 & .031 & 1.060 & .370 \\
\hline & \multirow[t]{3}{*}{ Within groups } & Jordanian female & .0000 & \multirow[t]{3}{*}{2.817} & \multirow[t]{3}{*}{96} & \multirow[t]{3}{*}{.029} & & \\
\hline & & American male & .0000 & & & & & \\
\hline & & American female & .0500 & & & & & \\
\hline & \multicolumn{3}{|c|}{ Total } & 2.910 & 99 & & & \\
\hline \multirow[t]{5}{*}{ Challenges } & $\begin{array}{c}\text { Between } \\
\text { groups }\end{array}$ & Jordanian male & .5000 & 5.933 & 3 & 1.978 & 3.647 & $.015 *$ \\
\hline & \multirow[t]{3}{*}{ Within groups } & Jordanian female & .0333 & \multirow[t]{3}{*}{52.067} & \multirow[t]{3}{*}{96} & \multirow[t]{3}{*}{.542} & & \\
\hline & & American male & .6000 & & & & & \\
\hline & & American female & .6000 & & & & & \\
\hline & \multicolumn{3}{|c|}{ Total } & 58.000 & 99 & & & \\
\hline
\end{tabular}

Table 4.10 reveals that there are statistically significant differences between the Jordanian and American characters in the use of hinder/block (Sig. = .035), in favor of the American male characters. This indicates that the American male characters employ more impoliteness strategies in their utterances than the other three groups, namely American female characters, Jordanian male and female characters. In addition, the analysis reveals that there are statistically significant differences in the use of the strategy challenges (Sig.=.015) in favor of the American male and female characters. The data analysis reveals that male characters in the two cultures use impoliteness strategies more than females do.

\section{B. Qualitative Analysis}

The present section presents the qualitative analysis and illustrates how the Jordanian and American male and female actors employed impoliteness strategies. The results are presented according to the taxonomies of impoliteness strategies used in the present study, with illustrative examples from the corpus. The excerpts below are selected from the Jordanian TV sitcom /dzalt'ah/ جلطة' Season 1 and the American TV sitcom 'The Big Bang Theory' Season 12 which included impoliteness strategies in the context in which they occurred. The utterances that included impoliteness strategies are underlined and discussed; in addition, the number of season (S.) and episode (Ep.) are offered next to each excerpt. 


\section{Criticize}

Criticize as an impoliteness strategy is used by a speaker to dispraise what others say or do or any other entity of the hearer (Bousfield, 2008). The excerpts below demonstrate how the Jordanian and American actors utilized this strategy in the TV sitcoms.

\section{Excerpt 1 (The Big Bang Theory, S. 12, Ep. 6)}

Amy (in a soft voice): Oh, but it's so far away, and I have such teeny, tiny legs.

Bernadette: Really? Our bodies? Is that where we're going, Amy?

Amy (normal voice): What's wrong with my body?

Sheldon: Well, for starters, you have a quarter in your nose.

Amy: Not now, Sheldon.

Excerpt 1 demonstrates how Sheldon, an American male actor, and Bernadette, an American female actor, employed the criticize strategy in the American TV sitcom 'The Big Bang Theory'. Sarcastically, Amy imitated Bernadette's soft voice and gave meaningless excuses for not joining them on a trip. In their response to Amy's sarcasm, Bernadette and Sheldon attacked her face by employing the impoliteness strategy of criticize, in which they dispraised her sarcasm. Bernadette said "Really? Our bodies? Is that where we're going, Amy?" to criticize Amy's silly reason for not going with her. Sheldon criticized Amy in the way she imitated Bernadette's voice by telling her that she has "a quarter in her nose". It can be noticed that the strategy is used to dispraise Amy's sarcasm.

Excerpt 2 (dzalt'ah/جلطة, S. 1, Ep. 9)

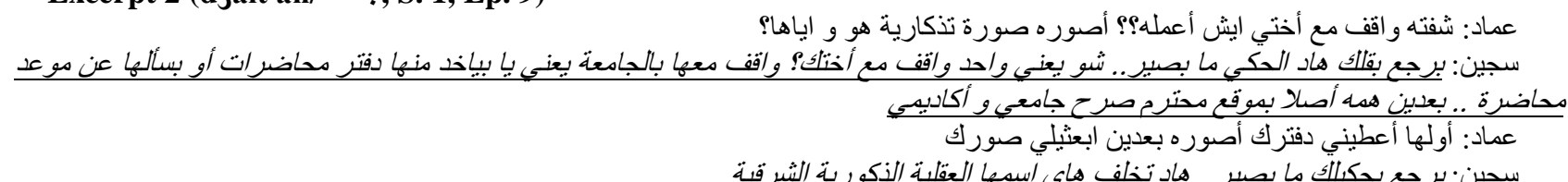

Emad: I saw him with my sister, what should I do?? Do you want me to take a memorial photo for both of them?

Prisoner: I repeat for you, this can't be...what is wrong with someone is standing with your sister? He is standing with her at the university; he is either taking a lecture notebook from her or is asking her about the time of the lecture... Also, they are in a respectable place, a university.

Emad: it starts with give me your notebook to copy it, and then send me your photos

Prisoner: I repeat again that this can't be... this is tardiness and called Eastern Masculine Mentality...

Excerpt 3 (dzalt'ah/جلطة, S. 1, Ep. 14)

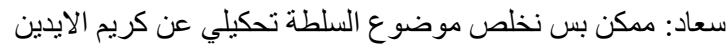

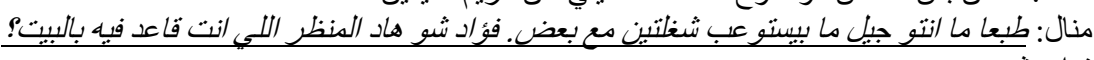

$$
\begin{aligned}
& \text { فؤاد: شورت طب مال } \\
& \text { منال: البيث كله صبايا يله قوم البس بنطلون }
\end{aligned}
$$

Suad: After we finish the salad issue, would you please tell me about the hands cream

Manal: of course, this generation cannot cope with two issues at the same time. Fuad, what is this thing that you are wearing at home?

Fuad: shorts

Manal: the house is full of females, go and wear your pants

Excerpt 2 presents an example on how the Jordanian male actors employed the strategy of criticize. The prisoner in Excerpt 2 above employed the criticize impoliteness strategy as a reply to Emad's excuse for being arrested. The prisoner dispraised Emad's action by saying:

$$
\text { شو يعني واحد واقف مع أختك؟ و اقف معها بالجامعة بعني يا بياخد منها دفتر محاضر ات أو بسألها عن مو عد محاضرة }
$$

(Tr. what is wrong with someone who is standing with your sister? He is standing with her at the university; he is either taking a lecture notebook from her or is asking her about the time of the lecture), asserting that it is normal for university students to take notebooks from each other, and criticizing Emad's mentality for being narrow-minded. The prisoner also added that هاد تخلف هابي اسمها العقلية الذكورية الثرقية (Tr. This is tardiness and called Eastern Masculine Mentality), criticizing Emad's way in dealing with a normal situation.

Excerpt 3 shows how Manal, a Jordanian female actor, used the criticize strategy in context. Suad was preparing the salad for lunch when suddenly her aunt Manal attacked her face and criticized her dry hands and advised her of using hand cream. Suad's response was that she had to finish the salad after which she would talk about her dry hands and the hand cream ممكن بس نخلص موضوع السلطة تحكيلي عن كريم الايدين (Tr. can you, when we finish the salad, tell me about hand creams?). Manal did not like Suad's criticism, so her response was criticizing her back as an impoliteness strategy to attack her face by saying طبعا ما انتو جيل ما بيستو عب شغلتين مع بعض (Tr. of course, this generation cannot comprehend two issues at the same time). Moreover, she ended the conversation with Suad and started criticizing what Fuad was wearing. Manal employed the criticize strategy to attack Fuad's face by saying فؤاد شو هاد المنظر اللي انت قاعد فيه بالبيت Fuad, what is this thing that you are wearing at home?) in which she dispraised his appearance in wearing shorts in front of his sister, which is considered inappropriate in the Jordanian culture..

Hinder/block 
According to Bousfield (2008), the impoliteness strategy of hinder/block can be employed physically by blocking the passage, or communicatively by denying the hearer's turn to speak or interrupting the speaker, or suddenly ending the conversation with the addressee. The examples below demonstrate how the hinder/block strategy was used in the TV sitcoms.

Excerpt 4 (The Big Bang Theory, S. 12, Ep. 3)

Leonard: Got a lot on my mind.

Amy: Would you like to talk about it?

Leonard: Not really.

Excerpt 5 (The Big Bang Theory, S. 12, Ep. 9)

Amy: I appreciate what you're trying to do but please stop. You can't make this better.

Penny: All right, Amy,..

Amy: Listen - I'm with Sheldon. We worked our butts off on this paper and it was all for nothing.

Excerpt 4 illustrates how Leonard, an American male actor, used the hinder/block strategy. Leonard was complaining to Amy that his wife Penny did not want to have children. When Amy asked him to elaborate on what annoys him, he considered her question as invasion to his personal space, so he blocked her by ending the conversation with "Not really". Using the strategy in this context might indicate that Leonard was hesitant in telling Amy about his personal life especially that Amy is Penny's close friend; therefore, he started complaining, but he changed his mind and ended the conversation.

Excerpt 5 presents how Amy, an American female actor, used the hinder/block strategy in the American TV sitcom 'The Big Bang Theory'. Penny was trying to make it easy for Amy because her research paper was rejected; Nonetheless, Amy was still angry and attacked her face by showing her disinterest in what she said "You can't make this better". However, Penny continued talking about it, which forced Amy to block her communicatively and interrupt her turn in the conversation saying "Listen - I'm with Sheldon. We worked our butts off on this paper and it was all for nothing".

Excerpt 6 (dzalt'ah/جلطة, S. 1, Ep. 18)

أم فؤاد: تعال افتح هالباب يا غضيب..

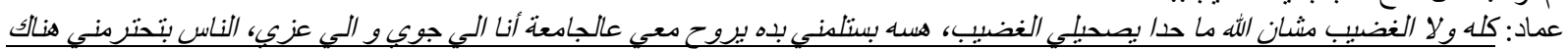

Um Fuad: come open the door, ungrateful son

Emad: I accept anything but not to wake up that ungrateful son ... now he will stick to me to go to the university with me, I have my mood, and my prestige... all people respect me there

Excerpt 7 (dzalt'ah/جلطة, S. 1, Ep. 18)

Abu Fuad: The important thing is God's guidance... Taurus star sign says that...

Um Fuad: May God burn Taurus and the one who brought up Taurus...

Excerpt 6 demonstrates how Emad, a Jordanian male actor, employed the hinder/block strategy. Emad heard his mother calling his brother, Fuad, to open the door by giving him another identity 'ungrateful' تعال افتح هالباب يا غضيب (Tr. come open the door, ungrateful son). However, Emad knew that Fuad is asleep and if he woke up, he would go with him to the university, and he did not want that to happen. Thus, he interrupted Um-Fuad and blocked her from finishing her utterance. In order to get rid of his brother, Emad employed the hinder/block strategy and attacked his mother's face when he said الغضيب مشان الله ما حدا يصحيلي الغضيب (Tr. For God sake, do not wake up that ungrateful son!).

Excerpt 7 presents how the Jordanian female actors employed the strategy hinder/block in context. Um-Fuad was complaining to Abu-Fuad about their son who was acting in a weird manner during the past days; however, he ignored her and started telling her horoscope المهم الهداية. برج الثور بقلك (Tr. The important thing is God's guidance... Taurus horoscope says that...). Um-Fuad realized that her husband ignored her; therefore, in response to his impoliteness (i.e., ignore, snub the other), she blocked him and attacked his face by interrupting his turn by saying الله يحرق برج الثور على اللي (it) (Tr. May God burn Taurus horoscope and the ones who brought up Taurus) as hinder/block impoliteness strategy.

Enforce role shift

The strategy of enforce role shift is employed by forcing the hearer out of one social and/or discoursal role into another (Bousfield, 2008). The following examples demonstrate how the Jordanian and American actors employed enforce role shift in the TV sitcoms. It is worth mentioning that the American male actors and the Jordanian female actors did not employ this strategy in their utterances at all.

Excerpt 8 (The Big Bang Theory, S. 12, Ep. 18)

Leonard: I do. But I'm-I'm really hogging this conversation.

Penny: Leonard? (clears throat) Just give them a chance.

Scientist: Uh, science has a history of difficult people.

Excerpt 8 shows how the American female actor, Penny, employed the strategy of enforce role shift in the American TV sitcom 'The Big Bang Theory'. In a gathering of scientists, Leonard controlled the conversation and played the role of the scientist who knows everything and everyone. Penny was annoyed because he did not give a chance to the 
scientist to participate in the conversation; therefore, she enforced him to shift roles to stop being the conversation dominator. Penny attacked Leonard's face and said "Leonard? (clears throat) Just give them a chance" to stop being the person who knows the whole story.

Excerpt 9 (dzalt'ah/جلطة, S. 1, Ep. 4)

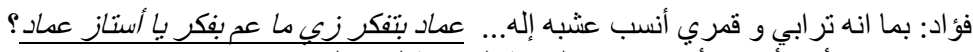

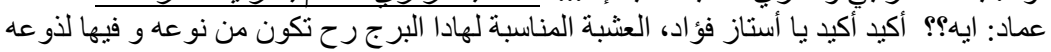

Fuad: since it is earthy and lunar, the best herb for it is....Emad do you think as the way I think Mr. Emad

Emad: what?? Of course, for sure Mr. Fuad, the suitable herb for this horoscope would be of the same kind of it, and it tastes pungent

Excerpt 9 shows how Fuad, a Jordanian male actor, used the strategy of enforce role shift in the Jordanian TV sitcom. Um-Fuad, Fuad, and Emad were recording a video for their social media channel, and they were discussing which herb is suitable for each horoscope. In order to have more followers, Fuad decided to be more convincing and pretended to be an expert of herbs. Therefore, he added a title to his brother's name and called him أستاز عماد (Tr. Mr. Emad) employing the strategy of enforce role shift to give him a higher social rank, which makes the audience believe him.

Challenges

According to Bousfield (2008), the challenge impoliteness strategy is employed by asking the hearer a challenging question, or questioning the hearer's position, stance, beliefs, and so on. The excerpts below illustrate how the Jordanian and American actors used the strategy of challenge in the two TV sitcoms.

\section{Excerpt 10 (The Big Bang Theory, S. 12, Ep. 18)}

Man: Who needs to be likable when you have Nobel Laureates campaigning for you?

Sheldon: Oh, yeah-- wait a minute. Do you not think we're likable?

Man: That's what's great about you, you never stop asking the tough questions.

Excerpt 11 (The Big Bang Theory, S. 12, Ep. 17)

Raj: So you really think you can trick Sheldon into liking babies?

Amy: I slept with him; I married him. You want to be against me?

Raj: Oh, you were right, Amy.

Excerpt 10 shows how Sheldon, an American male actor, used the impoliteness strategy of challenge. Sarcastically, a man told Sheldon that being in the Nobel Laureates is better than being likable. In response to the man's impoliteness (i.e., sarcasm and mock impoliteness), Sheldon challenged the man and questioned his opinion of being likable or not "Do you not think we're likable?". The man's response: "That's what's great about you! You never stop asking the tough questions" demonstrates that the man's face was attacked.

Excerpt 11 demonstrates how Amy, an American female actor, employed the challenge strategy. Raj insisted that Sheldon loved babies; however, Amy denied and stated that the last thing Sheldon would think of is having babies. Raj was not convinced and insisted on his opinion, which caused Amy to challenge his stance and respond by questioning his position "You want to be against me?" employing challenge as an impoliteness strategy to attack his face. In response, Raj agreed with Amy's opinion because he knew that he would lose the challenge since she knows her husband better.

Excerpt 12 (dzalt`ah/جلطة, S. 1, Ep. 15)

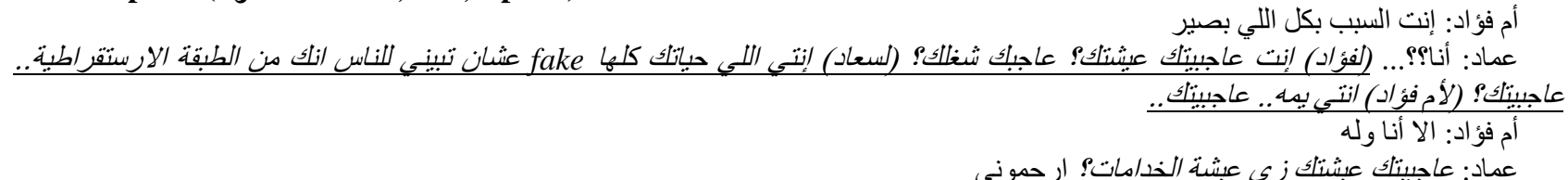

Um Fuad: you are the reason behind what has happened

Emad: me?? (to Fuad) Do you like the way you live? Do you like your job? (to Suad) your life is fake, you just show people that you are from the aristocracy ... do you like it? ( to Um Fuad) you mom ... do you like it...

Um Fuad: Hey, except me

Emad: do you like the way you live like maids? Have mercy on me

Excerpt 13 (dzalt`ah/جلطة, S. 1, Ep. 17)

Um Fuad: 1500 JDs only for cigarettes? Fuaaad

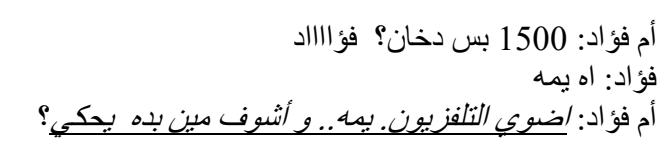

Fuad: yes mom

Um Fuad: turn on the television, mom ... and I let me see who is going to say anything?

Excerpt 12 shows how the Jordanian male actor, Emad, employed the strategy of challenge in the Jordanian TV sitcom. Um-Fuad was blaming Emad for the sadness of the family, and that it all happened because of his attitude. Emad was annoyed because the whole family blamed him for all the bad things. Therefore, he challenged their views and beliefs by asking 


\section{(لفؤاد) إنت عاجيتلك عيشتك؟ عاجبك شغلك؟ (لسعاد) إنتي اللي حياتك كلها fake عشان تبيني للناس انك من الطبقة الارستقر اطية.. عاجبيتك؟ (لأم}

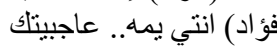

(Tr. (to Fuad) Do you like the way you live? Do you like your job? (to Suad) Your life is fake; you just show people that you are from the aristocracy. Do you like it? (to Um Fuad) You mom, do you like it?).

Emad confronted each one of them and attacked their face in the point that they actually do not like their lives, and they just blame him because they cannot say it out loud. It is noticed that Emad employed the impoliteness strategy of challenge to defend himself in front of his family.

Excerpt 13 demonstrates how Um-Fuad, a Jordanian female actor, employed the challenge strategy. Abu-Fuad blamed Um-Fuad for wasting their money, and that she is the reason behind being in debt. Suddenly, Fuad put his father's indebtedness on record and revealed the secret that the debt is because of the cigarettes that his father smoked. In order to express her anger, Um-Fuad told Fuad to turn the TV on, and, by doing so, she challenged Abu-Fuad أشوف مين بده يحكي (Tr. Let me see who is going to say anything). Um-Fuad used the strategy of challenge to express her shock and anger because Abu-Fuad was lying to her all the time.

\section{CONCLUSION}

The main aim of the present study was to investigate the cultural differences and similarities between the Jordanian and American characters in the use of impoliteness strategies in the American TV sitcom "The Big Bang Theory" and the Jordanian TV sitcom "dzalt using these strategies in the two TV sitcoms. It was found out that the Jordanian and American characters used the impoliteness strategies to attack the addressee's face or to respond to face attacks.

The data analysis revealed that the Jordanian characters used more impoliteness strategies than the American characters did. This might be explained by the fact that the Jordanian culture is a collectivistic culture; however, the American culture is an individualistic culture (Cheng, 2003). Another finding of the study is that male characters used more impoliteness strategies than the female characters did in both cultures, which agrees with previous studies on impoliteness and gender. This finding lends support to Mills (2002), Yating (2014), and Al-Yasin and Rabab'ah (2018), who concluded that males use more impoliteness strategies than females.

It is recommended that other researchers in the field of discourse analysis conduct comparative studies on TV sitcoms from more than two cultures to further explore the role that culture plays in the use of impoliteness strategies. Moreover, the researcher recommends studying the impact of gender on using impoliteness strategies in other Eastern and Western cultural contexts in order to generalize the finding that males use impoliteness more than females as a universal phenomenon. Further research can also investigate the use of impoliteness strategies in real life contexts not only in comedy TV sitcoms. It would also be interesting to study the use of impoliteness among individuals from different age groups in real life contexts.

\section{REFERENCES}

[1] Abdul Ghani, N. (2018). Online animosity: impoliteness strategies and triggers of hostility in a social networking site in Brunei. Southeast Asia: A Multidisciplinary Journal, 18, 71-84.

[2] Al-Shlool, S. (2016). (Im)Politeness and Gender in the Arabic Discourse of Social Media Network Websites: Facebook as a Norm. International Journal of Linguistics, 8.3, 31-58.

[3] Al-Yasin, N. \& G. Rabab'ah. (2018). Impoliteness strategies in 'The Fresh Prince of Bel-Air': A gender-based study. International Journal of Arabic-English Studies (IJAES), 18, 145-168.

[4] Aydınoğlu, N. (2013). 'Politeness and impoliteness strategies: an analysis of gender differences in Geralyn 1. Horton's plays'. Procedia - Social and Behavioral Sciences, 83, 473-482.

[5] Bousfield, D. (2008). Impoliteness in interaction. Philadelphia \& Amsterdam: John Benjamins. Brown, Penelope and Levinson, Stephen (1987), Politeness: Some Universals in Language Usage. Cambridge, United Kingdom: Cambridge University Press.

[6] Culpeper, J. (1996). Towards an anatomy of impoliteness. Pragmatics, 25.3, 349-367.

[7] Culpeper, J., D. Bousfield \& A. Wichmann. (2003). Impoliteness Revisited: With Special Reference to Dynamic and Prosodic Aspects. Journal of Pragmatics, 35, 1545-1579.

[8] Culpeper, J. (2005). Impoliteness and Entertainment in the Television Quiz Show: 'The Weakest Link'. Journal of Politeness Research, 1.1, 35-72.

[9] Culpeper, J. (2011). Impoliteness: Using Language to Cause Offense. Cambridge, United Kingdom: Cambridge University Press.

[10] Eckert, P. \& S. McConnel-Ginet. (2013). Language and Gender. Cambridge: Cambridge University Press.

[11] Hammod, N. \& A. Abdul-Rassul. (2017). Impoliteness strategies in English and Arabic facebook comments. International Journal of Linguistics, 9.5, 97-112.

[12] Kádár, D. \& S. Mills (2011). Politeness in East Asia. Cambridge, England: Cambridge University Press.

[13] Kecskes, I. (2015). Intercultural Impoliteness. Journal of Pragmatics, 86, 43-47.

[14] Lakoff, R. (1973). Language and Woman's Place. Language in Society, 2.1, 45-80.

[15] Mills, S. (2002). 'Rethinking politeness, impoliteness and gender identity'. In Lia Litosseliti and Jane Sunderland (Eds.), Gender Identity and Discourse Analysis, 69-90. Amsterdam, Netherlands: John Benjamins Publishing.

[16] Mills, S. (2003). Gender and Politeness, Cambridge: Cambridge University Press.

[17] Mills, B. (2009). TV Genres: Sitcom. Edinburgh, Scotland: Edinburgh University Press. 
[18] Mirhosseini, M., M. Mardanshahi \& H. Dowlatabadi. (2017). Impoliteness strategies based on Culpeper's model: An analysis of gender differences between two characters in the movie Mother. Journal of Applied Linguistics and Language Research, 4.3, 221-238.

[19] Rabab'ah, G. \& N. Nusiebah. (2019). Impoliteness in reader comments in AL-Jazeera channel news website. Journal of Politeness Research Language Behaviour Culture 16.1,1-22.

[20] Spencer-Oatey, H. (2008). Culturally speaking: Managing rapport through talk across cultures (2nd. edn.). London: Continuum.

[21] Tannen, D. (1990). You Just Don't Understand: Women and Men in Conversation. Ballantine Books, New York.

[22] Sinkeviciute, Valeria. (2017). What makes teasing impolite in Australian and British English? "Step[ping] over those lines [...] you shouldn't be crossing". Journal of Politeness Research, 13.2, 175-207.

[23] Watts, R. (2003). Politeness. Cambridge: Cambridge University Press.

[24] Yating, Y. (2014). 'Gender and conversational humor in a televised situational comedy: implications for EFL contexts'. English for Specific Purposes World, 43.15, 1-28.

Bayan B. Rababa'h is a PhD candidate who started her educational career as an English language teacher in 2002 and still developing in the educational field. She has worked as the Head of the English Department, and currently she is the Principal of the International programs at Universal Civilizations Academy in Amman, Jordan. She received her M.A. in Linguistics from the University of Jordan and is getting her Ph.D. degree by the end of 2020. Bayan's professional interests focus on communicative approaches in language teaching, cooperative learning, and inquiry-based learning. As a principal, one concern is developing teachers to equip students with the 21st century skills for they are the future generations. She has received a good number of certificates and awards from different educational institutions. She has also published two research papers in the fields of TEFL and Sociolinguistics.

Ghaleb Rabab'ah (Professor) is a full professor of Linguistics in the Dept. of English Language and Literature at the University of Sharjah. He published many papers in Linguistics, Applied Linguistics and ESL in international journals, such as Journal of Pragmatics, Poznan Studies in Contemporary Linguistics, Journal of Psycholinguistic Research, JALT CALL journal, and Babel. ORCiD: https://orcid.org/0000-0003-1804-5859. Scopus ID: 55207292200. 